\title{
Quantitative analysis of an experimental white spot syndrome virus (WSSV) infection in Penaeus monodon Fabricius using competitive polymerase chain reaction
}

\begin{abstract}
White spot syndrome virus (WSSV) has been a major pathogen of cultured Penaeus monodon Fabricius in Malaysia since 1994. As quantitative study on the replication of WSSV is in its infancy, competitive polymerase chain reaction (PCR) was used for quantitative study of an experimental WSSV infection per os in growout P. monodon. Gills, abdominal integument and abdominal muscle were selected for viral quantification. Infection was detectable as early as $14 \mathrm{~h}$ postinfection (h p.i.) in both gills and integument, but the infection in muscle was only detected at $24 \mathrm{~h}$ p.i. Gill tissue had the highest viral load, followed by integument and muscle. Typical viral growth curves were obtained for all organs with distinct phases of eclipse (0ï 24 h p.i.), logarithmic (24ї 48 h p.i.) and the plateau (48ï 120 h p.i.). Cumulative mortality rapidly increased from $48 \mathrm{~h}$ p.i. and reached $100 \%$ at the end of the plateau phase at $120 \mathrm{~h}$ p.i. Gross signs of white spots and reddish discoloration were also obvious in moribund individuals from the plateau phase. Based on the three phases of viral growth, WSSV infection was classified into light, moderate and heavy infection stages.
\end{abstract}

Keyword: Penaeus monodon; Polymerase chain reaction; Viral growth; White spot syndrome virus 